\title{
Issues of Classification of The Crime of Career Fraud In Uzbekistan
}

Vokhid Sunnatov, Tashkent State University of Law, Republic of Uzbekistan, ORCID: 0000-0001-7084555X; sunnatovv@mail.ru

\begin{abstract}
The crime of career fraud is one of the crimes that negatively affect the activities of the state and is committed by officials using their official powers, and is included in the Criminal Code of the Republic of Uzbekistan as a separate article. These are the problems in the qualification of this crime that we observe in practice today. In addition to highlighting the problems that exist in this article, we can see that the author has scientifically substantiated the problems related to the qualification of such crimes and put forward suggestions and recommendations.
\end{abstract}

Keywords: qualification, career fraud, robbery, property, property of others, crime, law, authority, power.

Received: 08.12.2020 $\quad$ Accepted: 16.01.2021 $\quad$ Published: 04.02.2021

\section{INTRODUCTION}

Qualification of career fraud is carried out according to certain rules. Rules of qualification of official forgery are the ways and means of application of the criminal law provided by it, provided by the leading decisions of Plenums of the Supreme Court of the Republic of Uzbekistan, and also created in other judicial practice and the theory of criminal law.

L.D. Gauxman divides the rules used in qualifying the falsification of evidence in a criminal case into three categories: general, private, and special rules. The specifics of qualifying career fraud and distinguishing it from similar crimes in terms of content are also based on the same rules [1].

Career fraud as an independent crime is very rare in practice. Its danger is mainly determined by the fact that it is usually associated with other crimes, primarily the crime of looting the property of others using their official position [2].

Although the Criminal Code lists different methods of looting, there is still no single approach to the criminal assessment of this aggression and forgery. Currently, there are two main views on the issue of qualification of such acts in the theory of criminal law.

According to the proponents of the first view, if career fraud was used as a means of committing or facilitating or concealing any other crime, including looting, the whole act was qualified under a set of articles of the Criminal Code providing for liability for these aggressions should be done [3].

Proponents of the second view argue that if career fraud acted as a method or means of looting the property of others, it should be covered by the last mentioned crime and therefore does not require additional qualification [4]. The use of official forgery or forged documents does not imply the direct transfer of property to others, but only as a means to achieve this goal or to conceal the traces of a crime a set of robberies and career fraud committed in a certain way [5].

However, proponents of the view that this structure of career fraud is covered by the looting of other people's property provide evidence that is not relevant to the nature of the issue under consideration [6]. To solve it correctly, here, too, it is necessary to follow the general rules of qualifying crimes according to their set. According to them, in practice, if the perpetrator commits two independent crimes, each of which is provided for in different articles of the criminal law, liability for a set of crimes is excluded only if one of the acts is a constitutional sign of another, more dangerous aggression.

It is known that career fraud is not a sign of any form of robbery. It is a separate crime that encroaches on its independent object. For this reason, whether career fraud was a method of facilitating or facilitating the looting of another's property, whether career fraud was committed after the robbery of another's property was completed, during or before the execution, is a matter for the perpetrator. actions should be qualified on a set of articles on career fraud and looting of property of others.

This conclusion is based on the guidelines set out in the decision of the Plenum of the Supreme Court of the Republic of Uzbekistan of 21 May 2004. Paragraph 8 of this decision states that if an official knowingly enters false information and records in official documents in order to mitigate or conceal the crime of robbery, his act must be qualified for a set of crimes under Articles 167 and 209 of the Criminal Code [7]. 
For example, citizen B. He has been working as a director of ELITA Limited Liability Company of Jizzakh Cotton Industry Association since December 11, 2017. Regulations on the procedure for the establishment and use of the Insurance Seed Fund, approved by the Cabinet of Ministers in April 2014; Technical warehouse of the State Standard of the Republic of Uzbekistan "Seeds" The warehouse manager $622,557.7 \mathrm{~kg}$, which was the responsibility of U.. 2,548,322,938 soums and 46,037.0 kg under the responsibility of the warehouse manager S. 240428261 soums, total 668,594.7 kg. By allowing $2,788,751,198$ soums worth of seeds to become unusable, the state's interests were severely damaged.

B. continuing his criminal activities, the warehouse manager U. with a prior criminal conspiracy of $1243.2 \mathrm{~kg}$. S65-24 selection variety for 7,818,484.8 soums, $19153.9 \mathrm{~kg}$. S65-24 selection variety for $65,276,491.2$ soums, $1481.7 \mathrm{~kg}$. Bukhara-102 selection variety for 7,075,177.5 soums and 15,105.5 kg. 67 597112.5 soums An-Boyavut-2 selection variety, total $36984.3 \mathrm{~kg}$. He sold 147,767,206 soums worth of seeds to unknown individuals who could not be identified during the investigationB. continuing his criminal activities, pursuing greed and low intentions, the chief accountant of the society Sh. Repeatedly falsified applications for employment of 20 people who did not work in the company, employment contracts, orders for employment by the director of the company, as well as false information that employees worked for 8 hours a day. , transferred 232,805,252 soums of salary funds to plastic cards opened in the bank in their name, plundered them by embezzling the amount of another's money.B. by the court. He was found guilty of committing the crimes specified in Article 207, Part 1, Article 167, Part 3, Subparagraph "a", Article 209, Part 2, Subparagraph "a", Article 205, Part 2, Subparagraph "a" of the Criminal Code [8].

There is no consensus among legal scholars as to how to qualify the perpetrator's actions if career fraud has served as a means or means of facilitating or concealing any other crime, including the looting of another's property. For example, FZ Khalikov writes: "If the consequences of career fraud are grounds for accusing a person of another crime (for example, looting of state or public property), the perpetrator's actions are classified as a set of crimes" [9].

According to BV Zdravomislov, forgery for the purpose of looting another's property is covered by the norm of the criminal law on falsification of documents, as it refers to the looting of another's property, including through abuse of office [10].

In our view, the composition of the looting of another's property does not include the falsification of documents, as the falsification of documents is not a method of self-looting. Forgery without proper use of the document does not lead to the seizure of property. Therefore, the use of such documents in the looting of another's property should be qualified for a set of crimes.

Career fraud can be committed in conjunction with other types of crimes, not just robberies, and is sometimes a method or means of committing them.

When career fraud is committed in conjunction with other crimes against public administration, the interests of the civil service and the interests of service in local self-government, there are questions about the competition of norms and the qualification of a real set of crimes. The problem of separating the set of criminal acts and the competition of criminal norms has not yet been fully resolved.However, as some authors rightly point out, a clear separation of the existence of a set of offenses and the competition of criminal law norms would allow the judiciary and investigators to avoid many of the errors that qualify different types of crimes [11].

The investigation of criminal cases by the bodies of preliminary investigation and the courts in determining the existence or non-existence of a set of crimes provided for in the criminal law of various chapters of criminal law in the qualification of official fraud and other crimes against public administration, civil service interests and service interests in local self-government, show that these norms face serious challenges when they compete with each other.

Sometimes a socially dangerous act committed by an official coincides with the signs provided for in Article two and in some cases - Article three of the Criminal Code. Due to this, the features of career fraud and abuse of power or official position, bribery, misappropriation of official powers, as well as the qualification of the act in competition with the norms of smuggling crimes require special analysis.

In determining the role and significance of the crime of official fraud and its relationship with other official crimes, it is necessary to proceed from the following. Career fraud has two sides: on the one hand - a special type of crime of abuse of power or official position under Article 205 of the Criminal Code; on the other hand, it is an official crime that has its own forms.

The fact that career fraud is a special component of the abuse of power or position gives grounds to consider the abuse of power or position, provided for in Article 205 of the CC, as a "reserve" component. The specific norm further defines the characteristics of the crime and differentiates the liability, which is more effective than the general norm in terms of prevention. People are generally 
warned in many ways that they know that the act they intend to commit is considered a crime in the Criminal Code [12].

At the same time, it should be noted that in practice, there are cases where actions similar to career fraud should be qualified under Article 209 of the Criminal Code, and not under Article 205 of the Criminal Code. As some authors rightly point out, such qualification is a way of committing abuse of power or official authority and is required in cases where it is combined with the unity of purpose and intent of the guilty official. In such cases, the general rule of qualifying offenses should apply when the whole and part are competing [13]. According to this rule, it is always necessary to apply a norm that fully covers all the factual signs of the act committed.

In such cases, career fraud acts as a method of abuse of power or official authority, and in the words of TB Basova, "the guilty person constitutes only one aspect of the criminal activity" [14]. For example, if the writing of a false statement is qualified as a career fraud, the other actions of the offender will not be given a proper legal assessment.

If the fraud did not directly define the commission of an abuse of power or position, but acted as a means of abuse of power or position, it would be appropriate to classify such actions under a set of Articles 205 and 209 of the CC. For this reason, it is not enough to qualify as an abuse of power or position only under Article 205 of the CC, when an official conceals a deficit resulting from the abuse of his / her official authority by accounting and confusing the reporting documents.Such actions would be more accurate if they were classified as abuse of office and career fraud [15].

For example, an official (chairman and members of the internal audit commission, inspectorinspector) does not promise to hide the robbery in advance, but knowingly commits a crime detected during financial control origin) hides.On the one hand, in such cases, the culprit does not perform the duty of notifying the supervisor who appointed the inspection or investigation of the identified violations, i.e., abusing his / her official powers. On the other hand, the culprit enters the investigation document with false information, that is, commits official fraud, violating the obligation to identify the identified robbery by examining the documents, ensuring the reliability of the inspection and investigation materials and the validity of the conclusions stated in the investigation document [16].

In this case, and in many other cases, career fraud is represented in one or more of the actions provided by law, and abuse of power or official authority may cover a wider range of illegal acts, depending on the form of its manifestation in practice.

Sometimes in judicial practice there is a question of the relationship between career fraud and another type of abuse of power or official authority - bribery. For example, an official gives a false document in exchange for a bribe, that is, he takes a bribe using his official authority, that is, he commits an act that is a crime in itself. In such cases, there is a real set of crimes, and the qualification of the crime requires a proper legal assessment [17]. This rule is now generally accepted.

According to the law, bribery is a crime committed in the interests of greed. In this case, the official must take advantage of his official position, or in exchange for the performance or non-performance of a certain action in the interests of the bribe-giver, he personally or through an intermediary, knowing that it is illegal to receive material benefits or property benefits.

According to the decision of the Plenum of the Supreme Court of the Republic of Uzbekistan of May 21,2004 , if the forgery was committed with the participation of other persons who are not subject to official crime it is explained that they should be qualified by Articles 28, 209 of the CC, not by the production, falsification, sale or use of forms " [18].

The legal literature also distinguishes a separate group of official crimes - alternative official crimes. The essence of these crimes is determined by the fact that they can be committed by both officials (using their official position) and non-officials [19]. From the point of view of the problem under analysis, an example of alternative-crime crimes is the composition of the crime of smuggling under Article 246 of the Criminal Code [21, 22]. The offense under Article 246 is often committed by using documents that are known to be forged or by entering false information into the documents.In this case, the decision of the Plenum of the Supreme Court of the Republic of Uzbekistan dated February 22, 1996 "On judicial practice in cases of smuggling and violation of customs legislation" states that "A person who submits a document to the authorities as a factual document shall be prosecuted under Article 246 and Article 209 or 228 of the Criminal Code for a set of crimes" [20].

In our opinion, it is wrong to qualify this act in this way. This is because the disposition of Article 246 specifically states that the use of a forged document is a special norm. Therefore, such an act does not require additional qualification under Articles 209 or 228. In this regard, the sentence in the second paragraph of subparagraph "d" of paragraph 3 of the decision of the Plenum of the Supreme Court of the Republic of Uzbekistan dated February 22, 1996 "On judicial practice in cases of smuggling and violation of customs legislation" should be worded as follows: 
"A person who knowingly forges a forged document or enters false information into a document or a forged document and submits it to the customs authorities as a valid document shall be prosecuted under Article 246 of the Criminal Code of the Republic of Uzbekistan. In this case, no additional qualification is required under Articles 209 or 228 of the Criminal Code of the Republic of Uzbekistan.

If the forgery was committed for the purpose of assisting another person to commit smuggling, the offender must be prosecuted for a set of crimes under Article 209 and Article 28, Part 5, Article 246 of the Criminal Code (for aiding and abetting the crime of smuggling). In conclusion to the above, it can be said that in all the components of the crime under consideration, the characteristics of the method of their commission apply as a factor of their competition.

\section{Conclusions}

1. The following conclusions were reached on the object of career fraud:

special object - the social relations providing protection of interests of bodies of the government, management and public associations and their normal activity according to the law;

related object - social relations providing normal and legal activity of state bodies and local selfgovernment bodies;

the main object directly - the circulation of official documents arising in the course of the activities of public authorities in the field of public service and the social relations associated with their issuance;

the direct additional object is the rights and legally protected interests of citizens or the interests of the state or the public.

2. Career fraud combines two interrelated criminal characteristics - the nature of the act committed by the person and the method of influencing the subject itself. As a sign of the objective side of the crime, fraud can also serve as a way to commit a crime, while acting as an independent act. In this case, it does not fully cover the criminal conduct.

3. The Plenum of the Supreme Court of the Republic of Uzbekistan should develop a resolution "On case law on cases of career fraud" and define the terms "falsification of documents" and "knowingly entering false information and records" as follows:

forgery of documents means the preparation of an official document that serves as proof of any fact, for the purpose of using it as a genuine and non-counterfeit document, or forged by other persons, ie forged, ie forged;

Deliberately inserting false information and records means preparing a false document expressing information that does not correspond to the truth or the actual state of affairs, as well as making various corrections to an official document that serves as proof of any fact in connection with or for the purpose of use; actions such as deleting or writing, altering other numbers, changing the date, deleting the actual text and writing another text instead, as well as taking appropriate formalities by unauthorized persons, in particular signing and making other similar changes.

4. In the disposition of part 1 of Article 209 of the Criminal Code it is expedient to use the conjunction "or" instead of the conjunction "and" between the words "compile" and "provide". Therefore, it is proposed to amend the disposition of Part 1 of Article 209 of the Criminal Code as follows:

"Official forgery, that is, the intentional entry of false information and entries in official documents, falsification of documents or the creation or submission of forged documents by an official of a state body, state-owned organization or citizens' self-government body for personal gain or other gain, is prohibited by law. causes serious harm to the protected interests or the interests of the state or the public."

5. It is expedient to distinguish the following types of career fraud:

1) material forgery - in this case, various corrections are made to the document, deletion or writing, changing other numbers, changing the date, deleting the original text and writing another text in its place, etc .;

2) intellectual forgery - a false, falsified document containing information that does not correspond to the truth or the real state of affairs.

6. The analysis of the definition of the concept of the official given by the law allows to come to the following conclusions:

this definition applies to all official crimes provided for in the Criminal Code of the Republic of Uzbekistan, in particular, to crimes against the administrative order established by Chapter XV of the Criminal Code and refers to the subject referred to in this Chapter;

the main criterion for defining the concept of the subject of crimes against management order is not the position held by the employee, but the powers granted to him.

7. It is expedient to add to the title and part 1 of Article 301 of the Criminal Code in the following order: 
"Article 301. Abuse of power, exceeding the authority of the authorities, or inaction of the authorities or official fraud.

Abuse of authority or service by a commander or other official, deviation from the scope of authority or service, as well as inaction or official fraud can cause significant damage or serious damage to the interests of the Armed Forces, the rights of servicemen or other citizens or protected by law. if there is a reason".

8. Career fraud can only be committed with the right intention. This is confirmed by the nature of the actions, the existence of motives for bias or other interests, and the fact that the law directly states that an act can be criminal only if the perpetrator knowingly enters false information into an official document.

9. It is proposed to aggravate the punishment for forgery under Article 209 of the Criminal Code in the following order:

"It simply came to our notice then.

a) by a repeat or dangerous recidivist;

b) committed by a group of officials with prior conspiracy (second part).

The same action:

a) by a very dangerous recidivist;

b) committed by a member of an organized group or in his interests;

c) causes a large amount of damage (part three).

10. It is expedient to state the sentence in the second paragraph of subparagraph " $\mathrm{d}$ " of paragraph 3 of the decision of the Plenum of the Supreme Court of the Republic of Uzbekistan from February 22, 1996 of No. 2 "About judicial practice on cases of smuggling and violation of the customs legislation" in the following edition:

"A person who knowingly forges a forged document or enters false information into a document or a forged document and submits it to the customs authorities as a valid document shall be prosecuted under Article 246 of the Criminal Code of the Republic of Uzbekistan. In this case, no additional qualification is required under Articles 209 or 228 of the Criminal Code of the Republic of Uzbekistan.

\section{References:}

1. Gauchman L. D. Qualification of crimes: law, theory, practice. 2nd edition, reprint. and additional-M.: JSC "center Yurinfor", 2003. 265-312 p.

2. Summarizing the judicial-investigative practice $7 \%$ of the criminal cases studied show that career forgery acts as an independent crime, $65 \%$ - with the looting of the property of other persons, $17 \%$ with other official crimes, $11 \%$ - the method of committing is combined with other crimes in which documents are forgery.

3. Sidorenko V. N., Tarasov A. A. Some issues of theft qualification in the sphere of financial and economic activity of military units // Law in the Armed Forces. - 2003. - No. 12. - P. 35.

4. Bugaevskaya N. V. Implementation of the functions of a representative of power as a sign of the concept of "official". / / proceedings of the Tula state University. - 2014. - no. 2. - P. 52.; Matyshevsky P. S. Responsibility for encroachments on socialist property in the Soviet criminal law: author. dis. ... doctor of law. - Kiev, 1970. - P. 25.

5. Borkov V. N. Qualification of official crimes. - Moscow: IST, 2018. - P. 165.

6. Kryukov N. I., Khalikov F. Z. Problems of qualification of official forgery. // Economy. Right. Society. 2016. - № 1 (5). - P. 70.

7. Resolution of the Plenum of the Supreme Court of the Republic of Uzbekistan No. 4 of 21 May 2004 "On Some Issues of Application of the Law on Punishment Liberalization to Economic Crimes".

8. Criminal case of the Jizzakh Regional Court on criminal cases № 1-13-1901/1 of March 15, 2019.

9. Khalikov F. Z. the Concept of the legislative process in the subjects of the Russian Federation. // Problems of law, 2012, no. 2, Pp. 28-30.

10. Borkov V. N. Delineation of official forgery from abuse of official powers. // Criminal law. - 2016. - no. 3. - P. 35.

11. Kozachenko I. Ya., Nikolaeva Z. A. The problem of the ratio of General and special compositions of officials // Jurisprudence. 1992. No. 3. - 40-48 p.; Shchepelkov V. F. Positions of the Plenum of the Supreme court of the Russian Federation regarding the qualification of official forgery. // Criminologist. - 2015. - № 2 (17). - Pp. 8-12.

12. Basova T. B. Responsibility for official forgery in criminal law of Russia: Textbook. / Under the editorship of prof. A.K.Korobeyeva - Vladivostok: publishing house of the far East. UN-TA, 2002. - P. 61.

13. Svetlov A. Ya. Theoretical problems of criminal responsibility for official crimes: author's thesis ... doctor of law. - Kiev, 1980.; 
14. Malinovskaya S. A. Modern problems of service forgery qualification. // Tribune of the scientist. 2019. - no. 12. - P. 139.

15. Basova T. B. Responsibility for official forgery in criminal law of Russia: Textbook. / Under the editorship of prof. A.K.Korobeyeva - Vladivostok: publishing house of the far East. UN-TA, 2002. - P. 63.

16. Romanov V.V Official forgery: a textbook. - SPb., 2017. - P. 138.

17. Sidorenko V. N., Tarasov A. A. Some issues of theft qualification in the sphere of financial and economic activity of military units. // Law in the Armed Forces. - 2003. - No. 12. - P. 35.

18. Voronin V. Competition of criminal law norms in cases of bribery and official crimes // The Russian justice. - 2003. - No. 11. - P. 25.

19. Basova T. B. Responsibility for official forgery in criminal law of Russia: Textbook. / Under the editorship of prof. A.K.Korobeyeva - Vladivostok: publishing house of the far East. UN-TA, 2002. - P. 65.

20. The set of decisions of the Plenum of Supreme Court of the Republic of Uzbekistan. 1991-2006. T.1. Tashkent: Teacher, 2007. - P. 43.

21. Kurbanov, M (2018) "GENERAL DESCRIPTION OF CRIMES RELATED TO OBSTRUCTION, UNLAWFUL INTERFERENCE IN BUSINESS ACTIVITY" ProAcademy: Vol. 1: Iss. 4, Article 14. Available at: https://uzjournals.edu.uz/proacademy/vol1/iss4/14

22. Kurbanov Marufjon Mamadaminovich. SOCIAL NEED TO DETERMINE LIABILITY FOR CRIMES RELATED WITH OBSTRUCTION, ILLEGAL INTERFERENCE IN BUSINESS ACTIVITY. Journal of Law Research. 2020, special issue 3, pp. 197-208. http://dx.doi.org/10.26739/2181-9130-2020-SI-3-24

23. Fayziyev Shokhrud Farmonovich Medical law and features of legal relations arising in the provision of medical services. International journal of pharmaceutical research Volume 11, Issue 3, July - Sept, 2019 P. $1197-1200 \quad$ doi:10.31838/ijpr/2019.11.03.088 http://www.ijpronline.com/ViewArticleDetail.aspx?ID=11016

24. Bryanskaya Elena, Fayziev Shokhrud, Altunina Anna, Matiukha Alena Topical Issues of an Expert Report in the Process of Proving in a Criminal Examination. International Journal of Engineering and Advanced Technology (IJEAT) ISSN: 2249 - 8958, Volume-9 Issue-1, October 2019 5345-5349 DOI: 10.35940/ijeat.A2946.109119 content/uploads/papers/v9i1/A2946109119.pdf

25. Fayziev Shokhrud (2019) Legal Aspects of Transplantology in the Republic of Uzbekistan. Systematic Reviews in Pharmacy, ISSN: 0976-2779, Vol: 10, Issue: 2, Page: 44-47 doi:10.5530/srp.2019.2.08 http://www.sysrevpharm.org//fulltext/196-1575419211.pdf?1586863081

26. Tulaganova, G. Some issues of observance of international legal norms of fight against legalization of criminal incomes in the Republic of Uzbekistan Journal of Advanced Research in Dynamical and Control Systems 12(2 Special Issue), c. 143-155

27. Bazarova D. Some problems of counteracting crimes related to laundering of illegal proceeds in Uzbekistan Journal of Advanced Research in Dynamical and Control Systems. Volume 11, Issue 7, 2019, Pages 873-885 